\title{
ADP/ATP Translocase 3
}

National Cancer Institute

\section{Source}

National Cancer Institute. ADP/ATP Translocase 3. NCI Thesaurus. Code C37303.

ADP/ATP translocase 3 (298 aa, $33 \mathrm{kDa}$ ) is encoded by the human SLC25A6 gene. This protein is involved in both the regulation of apoptosis and the exchange of cytoplasmic ADP for mitochondrial ATP across the inner mitochondrial membrane. 